\title{
Determinants of Economic Growth in Central Java
}

\author{
By: \\ Dimas Ruhen ${ }^{1)}$, Diah Setyorini Gunawan ${ }^{2)}$ \\ ${ }^{1,2)}$ Faculty of Economics and Business, Universitas Jenderal Soedirman \\ ${ }^{1)}$ Email: ruhendimas@gmail.com
}

\begin{abstract}
Central Java Province is one of the province in Java Island which has potential natural resources and human resources, but current Central Java economic growth is still far from other provinces on Java island. With the abudance of resources in Central Java the province and still low Growth Economics, this study analyze the effects of foreign investment, labor, and human capital investment, to the economic growth in ten regencies / city of Central Java Province. The analysis method in this study is using the panel data method with some criteria in the panel data, then the best model is the fixed effect or Least Square Dummy Variable (LSDV). The result of the research are: (1) Foreign investment has positive and insignificant effect, (2) the workforce has positive and significant influence, (3) human capital investment has positive and significant influence, (4) Semarang regency becomes the most economic growth area High compared with ten other districts / cities. The implications of this research are first, in increase the economic growth of ten regencies / cities in Central Java Province, the local government should create a conducive investment climate and simplify the investment licensing process so it will increase domestic and foreign investment and encourage economic growth. Second, the government's labor skill training can be an alternative for unskilled workers. Third, local governments can provide budget allocations for education and health so that the capital which portrayed by workers quality can deliver positive results.
\end{abstract}

Keywords: Economic Growth, Foreign Direct Investment (FDI), Labora, and Human Capital Investment

\begin{abstract}
ABSTRAK
Penelitian ini meneliti tentang faktor yang memengaruhi pertumbuhan ekonomi di Provinsi Jawa Tengah, berdasarkan pada teori pertumbuhan ekonomi neoklasik. Penelitian ini mencoba mengaitkan antara faktor penanaman modal asing, tenaga kerja, dan human capital investment, terhadap pertumbuhan ekonomi yang ada di sepuluh Kabupaten/Kota Provinsi Jawa Tengah. Metode analisis dalam penelitian ini menggunakan metode data panel dengan beberapa kriteria dalam data panel, maka model yang terbaik adalah adalah fixed effect atau Least Square Dummy Variable (LSDV). Hasil penelitian menunjukkan bahwa: (1) penanaman modal asing berpengaruh positif dan tidak signifikan, (2) tenaga kerja berpengaruh postif dan signifikan, (3) human capital investment berpengaruh posif dan signifikan. Implikasi dari penelitian ini yaitu pertama dalam upaya meningkatakan pertumbuhan ekonomi sepuluh kabupaten/kota di Provinsi Jawa Tengah, maka pemerintah daerah dapat menciptakan iklim investasi yang kondusif dan penyederhanaan proses perijinan agar penanaman modal baik yang bersumber dari dalam negeri maupun asing dapat semakin meningkat dan mendorong pertumbuhan ekonomi. Kedua, pelatihan keterampilan terhadap tenaga kerja yang dilakukan pemerintah dapat menjadi alternatif bagi tenaga kerja yang belum memiliki keterampilan. Ketiga, pemerintah daerah dapat memberikan alokasi anggaran untuk pendidikan dan kesehatan agar modal yang digambarkan oleh kualitas manusia dapat memberikan hasil yang positif.
\end{abstract}

Kata Kunci: Pertumbuhan Ekonomi, Penanaman Modal Asing (PMA), Tenaga Kerja, dan Human Capital Investment 


\section{INTRODUCTION}

Economic development is described by many economic expert. Generally, the term of economic development can be grouped into two parts, based on time period based on traditional economic (the traditional paradigm) and new paradigm of economic development (Rostow, 1956). The traditional paradigm sees that development is identified with the effort of increasing income percapita or known as economic growth strategy. Initially, the difference between developed and developing is assumed by the percapita income of the countries. Increasing the income percapita is expected to solve unemployments problem, poverty, and inequality of income distribution.

The tendency is visible from early thougths on develompent such Harrod Domar theory, and Rosentein Rodan. Economic development solely viewed from economic growth. New paradigm realize that development is not similar with growth course, in new paradigm, the economy must be contain with problem solving such as reducing unemployment, poverty, income gap. Generally, economic growth is neccesary but not sufficient to the developing process. Successful of development is not separated from economic planning which means as efforts by government to coordinate the decision making of long-term economy and to influence, directing, and controlling the level and growth of economc variables (Todaro and Simith, 2006). Construction of the-dimensional region in general are often referred to as regional economic development, such as the economic development of the regions of both provinces or Regions/City. In the context of the operational development of dimensional areas related to development activities conducted in specific areas which are the region's development.

Indicators of the success of the implementation of the development that can be used as benchmarks in the macro is economic growth. According to Boediono in Tarigan (2007) said that economic growth is the increase in output in the long run. Economic growth can be described the pace of growth of the gross Regional domestic product (GDP). However, although it has been used as an indicator of development, economic growth has not reflected the condition of the community individually. One of the provinces in Indonesia, especially in Java that has thepotential of high economic growth is Central Java. Central Java has natural resources and sufficient human resources potential. Central Java recorded an area of 3.25 million hectares or 25.04 per cent of the island of Java (1.70 percent of Indonesia) and Central Java is one of the province's national food buffer. In addition to that by 2015 the Central Java recorded a total work force as much as $17,298,925$, the number of the labour force to make Central Java became the province with the third largest number of work force compared with the existing in Java, the first rank is occupied by the province of East Java with a total work force as much as $20,274,681$ inhabitants and the second stage is occupied by the West Java province with a total work force as much as 20,586,356 inhabitants (Statistics Indonesia ,2016.). In Figure 1 shows the condition of the economic growth in the six provinces on Java.

In Figure 1 to see that economic growth ranks first occupied by Banten Province with an average economic growth of 6.27 percent. Jakarta was ranked second with a percentage of the average growth of the gross Regional domestic product (GDP) amounted to 6.22 percent. East Java and West Java province ranked third and fourth with an average GDP growth of 6.09 pesen and 5.89 percent. From the Figure 1.1 can be concluded that the average economic growth rate of Central Java province and Yogyakarta (DIY) including low because under the national economic growth that is amounted to 5.74 percent. Figure 1 is also seen economic growth of central java province and Yogyakarta is still less than the existing provinces in Java. 


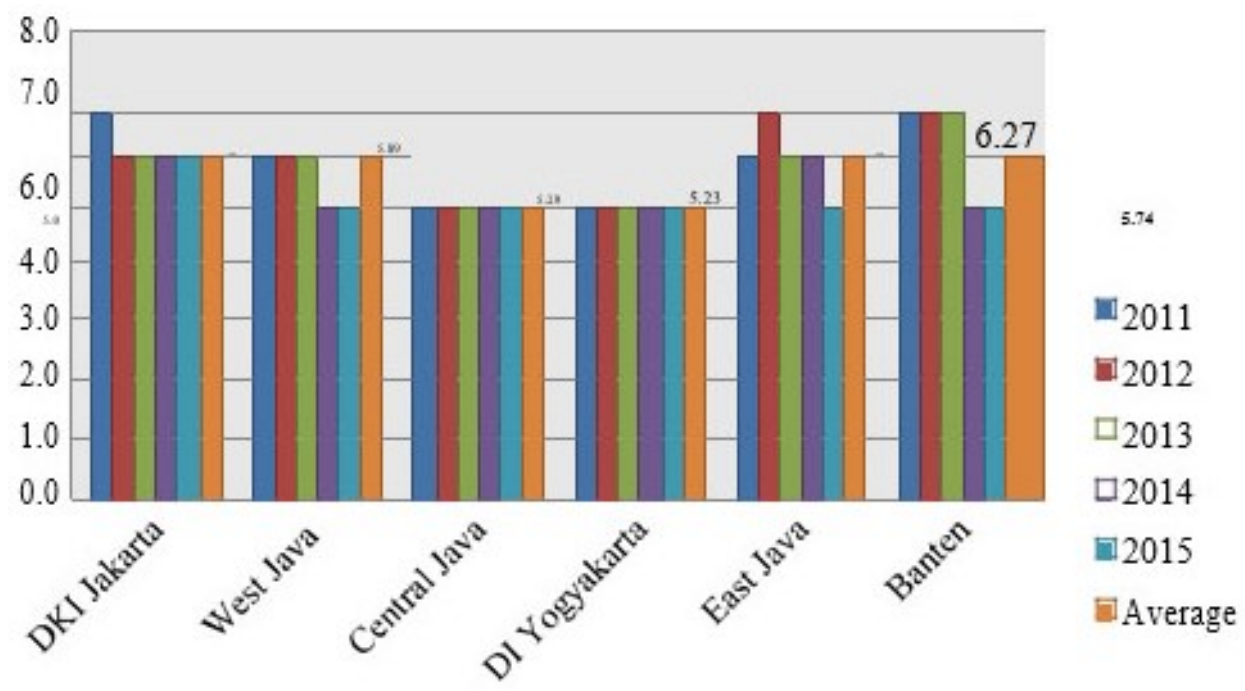

Figure 1. Economic Growth of Six Provinces of Java 2011-2015 Source: Central Bureau of Statistics

Economic development is in multidimensional process not only pursue economic growth only. Economic development includes various aspect such as the handling of imbalaces between regions or income, as well as alleviating poverty (Todaro and Smith 2006), these aspect are synergized to achive success in development where a new paradigm also looked at these things are very important. In 2011-2013 Central Bureau of statistics noted the economic gap between the region and the city of Provincy in Central Java and the gap at the national level. Figure 2 shows the economic gaps of Central Java and at the national level.

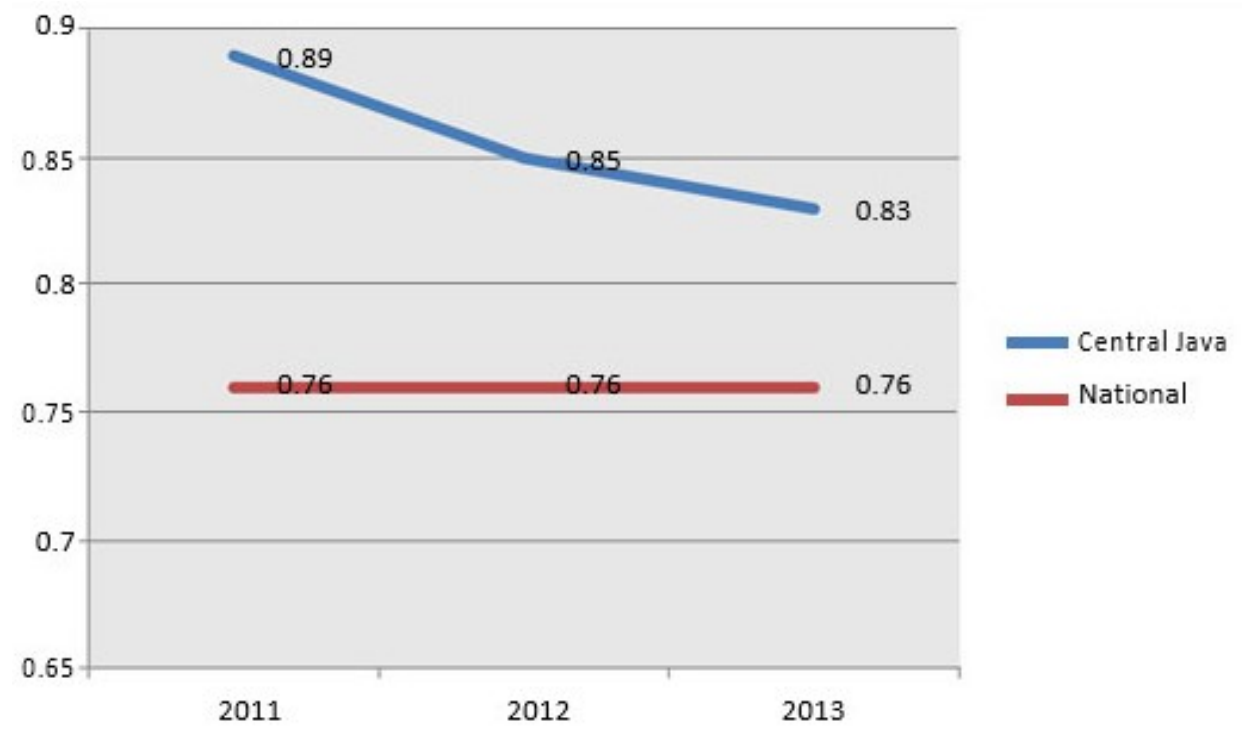

Figure 2. The Gap of Economic Growth (Indeks Williamson) 2011-2013

Source: Central Bureau of Statistics

Figure 1.2 illustrates the level of each city and district economic gap in Central Java, indicated by index value Williamson from 2011-2013 has a tendency to decline and are above the national average. Based on data from the Central Bureau of statistics, cited by the Government of Central Java (2015), the gap in Central Java belongs to the category of economic disparity. The cause of economic and social inequalities in Central Java was the structure of theeconomy in counties and cities in Central Java. Some areas of industrial and urban areas is a fairly advanced while another area is rural economy activity only dominated by agriculture. This is the one that is causing the gap getting 
bigger.The Organization of local governments as sub state system intended to improve the effectiveness and results to the Organization of Government and community service as a autonomous region, Regions/Cityto act as a driving force while the government as the Coordinator has the authority and responsibility for organizing government that aims to consider the interests of the community and the presence of independent regions as well as forward. Central Java is the province which includes thirty five Regions/City with varying levels of economic growth.

Table 1. Economic Growth of Central Java According to Regions/Cities in 2011-2015 (in Percent)

\begin{tabular}{|c|c|c|c|c|c|c|}
\hline \multirow{3}{*}{ Regions/cities } & \multicolumn{5}{|c|}{ Year } & \multirow{3}{*}{ Average } \\
\hline & & & & & & \\
\hline & 2011 & 2012 & 2013 & $2014^{*}$ & $2015^{* *}$ & \\
\hline Cilacap Regions & 4.07 & 1.98 & 1.66 & 2.93 & 6.46 & 3.42 \\
\hline Banyumas Regions & 6.61 & 5.88 & 6.97 & 5.67 & 6.12 & 6.25 \\
\hline Purbalingga Regions & 5.67 & 5.79 & 5.27 & 5.86 & 5.39 & 5.59 \\
\hline Banjarnegara Regions & 5.44 & 5.23 & 5.44 & 5.27 & 5.48 & 5.37 \\
\hline Kebumen Regions & 6.15 & 4.88 & 4.57 & 5.80 & 6.29 & 5.53 \\
\hline Purworejo Regions & 5.64 & 4.59 & 4.94 & 4.49 & 5.12 & 4.95 \\
\hline Wonosobo Regions & 5.37 & 4.70 & 4.00 & 4.89 & 5.12 & 4.81 \\
\hline Magelang Regions & 6.68 & 4.88 & 5.91 & 4.88 & 5.35 & 5.54 \\
\hline Boyolali Regions & 6.34 & 5.33 & 5.83 & 5.42 & 6.06 & 5.79 \\
\hline Klatem Regions & 6.29 & 5.71 & 5.96 & 5.79 & 5.64 & 5.87 \\
\hline Sukoharo Regions & 5.88 & 5.90 & 5.78 & 5.40 & 5.69 & 5.73 \\
\hline Wonogiri Regions & 3.58 & 5.94 & 4.78 & 5.30 & 5.34 & 4.98 \\
\hline Karanganyar Regions & 4.95 & 5.90 & 5.69 & 5.22 & 5.05 & 5.36 \\
\hline Sragen Regions & 6.55 & 6.12 & 6.70 & 5.58 & 6.05 & 6.20 \\
\hline Blora Regions & 4.42 & 4.90 & 5.36 & 4.39 & 5.36 & 4.88 \\
\hline Rembang Regions & 5.19 & 5.32 & 5.43 & 5.14 & 5.49 & 5.31 \\
\hline Pati Regions & 5.91 & 5.93 & 5.97 & 4.63 & 5.98 & 5.68 \\
\hline Kudus Regions & 4.24 & 4.11 & 4.36 & 4.47 & 4.08 & 4.25 \\
\hline Jepara Regions & 4.92 & 5.86 & 5.39 & 4.80 & 5.03 & 5.20 \\
\hline Demak Regions & 5.39 & 4.46 & 5.27 & 4.29 & 5.93 & 5.06 \\
\hline Semarang Regions & 6.27 & 6.03 & 5.97 & 5.84 & 5.43 & 5.90 \\
\hline Temanggung Regions & 6.09 & 4.27 & 5.20 & 5.06 & 5.17 & 5.15 \\
\hline Kendal Regions & 6.67 & 5.21 & 5.21 & 6.22 & 5.17 & 5.66 \\
\hline Batang Regions & 6.12 & 4.62 & 4.62 & 5.88 & 5.60 & 5.23 \\
\hline Pekalongan Regions & 5.66 & 4.81 & 4.81 & 5.99 & 4.78 & 5.23 \\
\hline Pemalang Regions & 5.01 & 5.32 & 5.32 & 5.57 & 5.50 & 5.38 \\
\hline Tegal Regions & 6.39 & 5.23 & 5.23 & 6.73 & 5.45 & 5.76 \\
\hline Brebes Regions & 6.65 & 4.58 & 4.58 & 5.91 & 5.97 & 5.68 \\
\hline Magelang City & 6.11 & 5.37 & 5.37 & 6.04 & 5.07 & 5.49 \\
\hline Surakarta City & 6.42 & 5.58 & 5.58 & 6.25 & 5.54 & 5.81 \\
\hline Salatiga City & 6.58 & 5.53 & 5.53 & 6.30 & 5.14 & 5.81 \\
\hline Semarang City & 6.58 & 5.97 & 5.97 & 6.25 & 5.79 & 6.19 \\
\hline Pekalongan City & 5.49 & 5.61 & 5.61 & 5.91 & 5.00 & 5,49 \\
\hline Tegal City & 6.47 & 4.21 & 4.21 & 5.67 & 5.43 & 5.36 \\
\hline
\end{tabular}

* preliminary figure

** very preliminary figure 
According to Table 1, the highest economic growth is Banyumas with 6.25 percent then Sragen with 6.20 percent, and Semarang 6.19 percent meanwhile the lowest economic growth average is Cilacap with 3.42 percent. The data shows the uneven distribution od rural-urban in Central Java make the Government should courage the natural resources to improve the economic growth.

Solow's Neoclassic theory explain how the capital and labor quantity influence the economic growth of a country or area. Investment become the development capital as well which explain by Harrod Domar theory. Previous researches that observed about the association between foreign investment, labor, and human capital investment have done like Hasanah (2016) found that there was positive and significant relation between human development index and labor. Hikmatiyar (2015) also stated that there is a positive and significant relation between foreign investment and economic growth in Central Java during 1995-2009.

Investment has important role in stimulate the economic growth. Therefore, investment from foreign investment become one ofthe development funding source and economic growth. Foreign investment, directed to replace the foreign debts as source of development funding and growth or regional development. Foreign investment become more important within globalization era give the authorization for regional to look for funding abroad. Syahrani (2011) stated that there was significant and positive relation of foreign investment to economic growth in 1958-2009.

According to Neoclassic theory, one of economic growth source is increasing of labor quality and quantity. Labor quantity shows from the number of citizens. Todaro and Smith (2006) also said that fertility growth and labor force growth are the positive factor to stimulate the economic growth. The higher labor shows the domestic is higher. Previous research which used labor as the point of economic growth stated that within labor increasing will influence positively to economic growth (Chong, Hong, and Wenqin (2012), and Pambudi (2013).

Education is fully influence to economic growth of a country or region. It is not only caused by education to productivity but also to fertility. Education can make the human resources understand faster and ready to face the improvement and development of a country and region. Socio-economic development concept has varies depend on user's context. The economists develop the development process and known further as Human Capital Investment (Schultz, 1961).

The concept is considered that human is one of capital like the others (machines, technologies, lands, money, and materials). Human as human capital showsh in knowledge, ideas, creativities, creations, and work productivity. Not likely the other capitalsas tools, human capital can invest themselves through many ways such as fromal and informal education, work experience, health, or nutrition, or even migration. Research by Budiarti and Soestoyo (2012) in Mojokerto discover the conclusion that high school education is significantly and positively affected to economic growth.

Central Java is one of the province in Java which has potential natural resources and human resources. Central Java is about 3.25 million hectare or 25.04 percent of Java (1.70 percent of Indonesia) and Central Java is the pioneer of National food. Besides, Central Java has labor force $17,298,925$ in 2015 , the number of labor force make Central Java become the third of labor force number compare with other province such East Java in first $(20,274,681)$ and the second is West Java $(20,596,358)$ (Central Statistic Bureau, 2016).

But the current economic growth of Central Java is still far behind other Provinces in Java, it can be seen from Figure 1.1. where Central Java province ranks second lowest before Provincies in Yogyakarta in average economic growth. When compared with the growth of the national economy of Central Java is also still below the average national growth. How the influence of foreign investment, labor, and human capital investment to economic growth in ten regions/ cities of Central Java in 2011-2015?

\section{HYPOTHESIS DEVELOPMENT AND RESEARCH MODEL}

\section{Effect of Foreign Direct Investment to Economic Growth}

Neoclassic economic growth theory and Harrod-Domar theory stated that there is positive relation between foreign investment to economic growth. Novianto (2013), Dewi (2013) stated that foreign investment affected positivelly to economic growth. Higher level of foreign investment in a region 
the highest accumulation of capital as well. Increasing of foreign investment will raise the productivity capacity, aggregate demand, and the posibility of technology transfer so the production is more efficient and the porductivity increase as well, and could create high level of economic growth. Based on the explanation above, the following hypothesis is:

$\mathrm{H}_{1}$ : Foreign investment positivelly effect to economic growth in regions/ cities of Central Java

\section{Effect of Labor to Economic Growth}

Neoclassical theory stated that increasing the quality and quantity of population will increase labor and labor increasing adfect the economic growth because it could become movers of economic growth.

Previous research by Pambudi (2013), Barimbing (2015), Karmini (2015), and Chong, Hong, Wenqing (2012) stated that number of labor influemce the economic growth. Logically, by Increasing the number of labor, the productivity will increase as well in several sectors. Based on the explanation above, the following hypothesis is:

$\mathrm{H}_{2}$ : Labor have positive effect to economic growth in Regions/City of Central Java

\section{Effect of Human Capital Investment to Economic Growth}

Human capital investment theory stated that formal education is the most important instrument to produce pople with high productivity (Schultz, 1961) and according to Alhumami in Subroto (2004) stated that education produce quality of human resources, have knowledge, and skill also mastering technology will build.

Research by Ndambiri, Ritho , Ng'ang'a, Kubown, Mairura, Nyangweso, Muiruru and Cherotwo, (2012). Chong, Hong and Wenqing PAN, (2012) stated that human resources forming or human capital investment is positively affect to economic growth. Based on the explanation above, the following hypothesis is:

$\mathrm{H}_{3}$ : Human capital investment effect positively to economic growth in Regions/City of Central Java

\section{Research Model}

Economic growth beccome the most important indicator of succed the economic development, it because economic growth is describe the real effect of develompent policies especially in economic sector. Economic growth in Central Java show from Gross Domestic Bruto (GDB) every year. Economic growth is influenced by several factors. In this research, the factors imfluence the economic growth $(Y)$ will be discussed such as foreign direct investment (X1), number of labor (X2), and human capital investment (X3).

Harrod-Domar theory said about how important investment in economic growth is. Investment is capital of regulation development economic activity, it because the additional of investment will increase the goods and services production of a country or region, it will affect the economic growth to the next period. But because effect of investment is long-term, then the investment increase will increase the eonomic growth in one or two next period because there is a time lag.

Labor is a potential resources as Movers, visionary, and implementing regional development in the area. By the population growth will inrease the labir force and increase the productivity and production capacity as well.

Education level is the main capital of human resources to push the e onomic growth. Humman caital theory said that formal education is the most important inatrument to peoduce high quality and high productivity so people who have skill and can operate technology, will grow business climate condusively for the economic growth. 


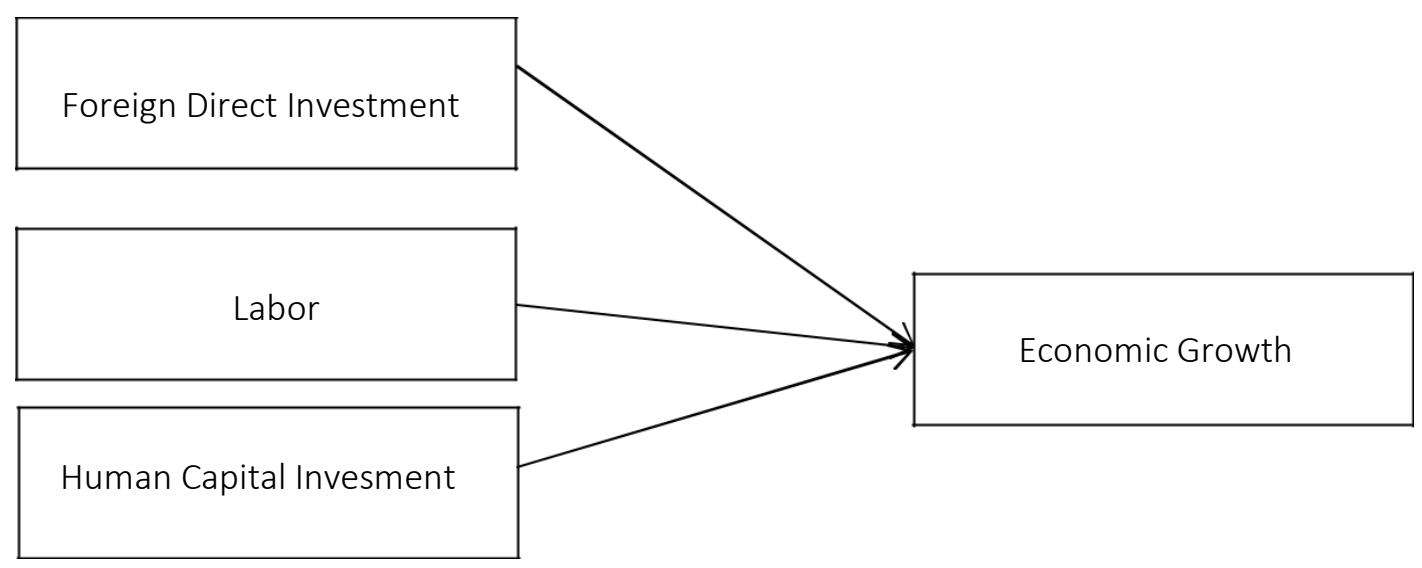

Figure 2. Research Framework

\section{RESEARCH METHOD}

\section{Model Estimation}

This research talk about the influence of foreign direct investment, labor, and human capital investment use the time series of five years which represented data from 2011-2015 and cross section data is 35 . The research method is semi log with the variables are FDI, and labor is transformed through natural logaritm (lin-log). Lin-log model is benefical on relative changing of $X$ will impact the absolute transform to dependent variable $Y$ (Nachrowi dan Usman, (2002).combination or pooling give 175 observation with the formulation of data panel is:

$$
Y_{i t}=\beta_{0}+\beta_{1} \ln X_{1 i t}+\beta_{2} \ln X_{2 i t}+\beta_{3} X_{3 i t}+\varepsilon_{i t}
$$

Description:

$\begin{array}{ll}\mathrm{Y} & =\text { Economic Growth } \\ \ln X_{1} & =\text { Foreign Direct Investment } \\ \ln X_{2} & =\text { Labor } \\ X_{3} & =\text { Human Capital Investment } \\ \mathrm{i} & =\text { cross section } \\ \mathrm{t} & =\text { time series } \\ \beta_{0} & =\text { constant } \\ \beta_{1}, \beta_{2}, \beta_{3} & =\text { Coefficient } \\ \varepsilon & =\text { error term }\end{array}$

\section{Chow Test}

Chow test is a test to choose between commkon or fixed effect to use for classical assumption test and statistical test. To choose the best method, the Chow test is done as follow:

$\mathrm{H}_{0} \quad$ : common effect model.

$\mathrm{H}_{1} \quad$ : fixed effect model.

If $\mathrm{F}$ count is bigger than $\mathrm{F}$ statistic, means that $\mathrm{HO}$ is reejcted and $\mathrm{H} 1$ is accepted, so the model is fuxed affect. Thus, if $F$ count is less than F statistic, then $\mathrm{HO}$ is accepted and $\mathrm{H} 1$ is rejected, so the model is common effect (Widarjono, 2009).

\section{Lagrange Multiplier (LM) Test}

LM test is used to know whether random effect model is better than common effect. To choose the best method, the hypotheses of LM test are:

$\mathrm{H}_{0} \quad$ : common effect model.

$\mathrm{H}_{1}$ : random effect model. 
If LM statistic is bigger than critical value of chi-square then $\mathrm{HO}$ is accepted and $\mathrm{H} 1$ is rejected, so the model is common effect (Widarjono, 2009).

\section{Hausman test}

Hausman test is used to choose between fixed effect and random effect. To q2choose the best method so the hypotheses of hausman test as follows:

$\mathrm{H}_{0} \quad$ : random effect model.

$\mathrm{H}_{1} \quad$ : fixed effect model.

If the probability is less than $5 \%, \mathrm{HO}$ is rejected and $\mathrm{H} 1$ is accepted, means that the best model is fixed effect. Thus, if the probability more than $5 \%, \mathrm{HO}$ is accepted and $\mathrm{H} 1$ is rejected, mean that the best model is random effect (Widarjono, 2009).

\section{Multicollinearity Test}

At beginning, multicollinearity mean there is a perfect correlation between one or entire variables in a regression model. Clearly, multicollinearity means that there is a linear correlation (Gujarati dan Porter, 2013). Besides, to detect a multicollinearity can be done by using the auxiliary regression which means apply regression to independent variable. If $R 2$ of auxiliary regression higher than the main R2, there is no multicolliniearity happens (Suprapto, 2010).

\section{Heteroscedasticity and Autocorrelation Test}

Heteroscedasticity shows if the residu does not have constant variance on each other observation. Heteroscedasticity much happen in cross section data. Autocorrelation happen because successive observation related to one another. This probles apears because residual is not free from one another observation. Autocorrelation much appears in time series data (Mudrajat Kuncoro, 2004).

In this research, heteroscedasticity and autocorrelation are not tested because this research is using data panel which has several advantages, as follow (Gujarati dan Porter, 2013):

(1) Data panel estimation technique can solve heteroscedasticity.

(2) Data panel can minimize bias that may happen when aggregate individuals to big aggregation.

(3) Data panel let us learn about complexity in a model.

\section{Goodness of Fit}

The model used is expected to get a proper value for estimator or in accordancewith that desired of goodness of fit. This testis seen from coefficient determination so it is proper to describe the dependent variance (Widarjono, 2009).

$$
\mathrm{R}^{2}=\frac{\mathrm{ESS}}{\mathrm{TSS}}=1-\frac{\mathrm{RSS}}{\mathrm{TSS}}=1-\frac{\sum e_{i}^{\frac{2}{i}}}{\sum e_{\frac{1}{1}}^{2}}
$$

Description:

ESS = Explain Sum of Squares

TSS $=$ Total Sum of Squares

RSS $=$ Residual Sum of Squares

Coefficient determination (R2) show the number of variance from dependent variable (economic growth) which can be explained by independent variable (aglomeration, labor, human capital investment, and regional income). The limit is $0<r 2<1$. R2 equal 1 means that the perfect fit and $\mathrm{R} 2$ equal to 0 mean that ther is no correlation between dependent and independent variables.

\section{Simultanous Test ( $F$ test)}

$F$ test is basically used to know if the independent variables is influence the dependent variable. To test the coefficient regression, the formulation for $F$ test as follow (Ghozali, 2009): 
Description:

$$
\mathrm{F}=\frac{\mathrm{R}^{2} /(\mathrm{k}-1)}{\left(1-\mathrm{R}^{2}\right) /(\mathrm{n}-\mathrm{K})}
$$

$\mathrm{R}^{2}$ : Coefficient determination

$\mathrm{n} \quad$ : Samples number

$k$ : Number of variables

$\mathrm{F}$ : The amount of $\mathrm{F}$

$\mathrm{H}_{0}$ accepted and $\mathrm{H}_{1}$ rejected if $\mathrm{F}$ count less than $\mathrm{F}$ table which mean that independent variables are not sigificant affect dependent variable.

$\mathrm{H}_{0}$ rejected and $\mathrm{H}_{1}$ accepted if $\mathrm{F}$ count higher than $\mathrm{F}$ table which mean that independent variable are signifianctly affect the dependent variable.

\section{Partial Test ( $t$ Test)}

T test is used to know sigficantly level of each aglomeration, labor,human capital investment, and regional income to economic growth partially. T test will be done by using following formula (Ghozali, 2009):

\section{Descriptiom:}

$$
\mathrm{t}=\frac{\mathrm{b}_{\mathrm{i}}}{\operatorname{Se}\left(\mathrm{b}_{\mathrm{i}}\right)}
$$

$\mathrm{t}=\mathrm{t}$ count amount

$b_{i} \quad=$ coefficient regression partial

$\mathrm{Se}\left(\mathrm{b}_{\mathrm{i}}\right) \quad=$ error term of coefficient regression

$H_{0}: b_{1}=0$

Statistic hypotheses:

$H_{0}: b_{1}=0$ means that inependent variables are not significantly affect the dependent variable.

$H_{0}: b_{1} \neq 0$ means that independent variables are significantly affect the dependent variable.

With the criteria as follow:

$\mathrm{H}_{0}$ is accepted if $\mathrm{t}$ count less than $\mathrm{t}$ table or sig is higher than alpha, it means that independent variables are not significantly affect the dependent variable.

$\mathrm{H}_{0}$ is rejected if $\mathrm{t}$ count higher than $\mathrm{t}$ table or sig less than alpha, it means that independent variables are significantly affect the dependent variable. T table calculation in this research is using level of significant 5 percent or 0.05 and the conviction rate is 95 percent or 0.95 . so if the error level a variable higher than 5 percent or 0.05 means that the variable is not significant.

\section{RESULT}

\section{Chow test}

Chow test is used to choose the model between ecommon effect model and fixed effect. Chow test is done by follow hypotheses:

$\mathrm{H}_{0}$ : Common effect model

$\mathrm{H}_{1}$ : Fixed effect model

If the failure probability valued less than $5 \%(0.05)$, then $\mathrm{H}_{0}$ can be rejected and $\mathrm{H}_{1}$ can ot be rejected which means that model used is fixed effect. In other hand, if the probability value is more than $5 \%$ then $\mathrm{H}_{0}$ is cannot be rejected and $\mathrm{H}_{1}$ can be rejected which means that the model used is common effect moddel. Based on the result Chow Test value of Cross-section Chi-square (0.0386) is 
less than 0.05 mean $\mathrm{H}_{0}$ can be rejected and $\mathrm{H}_{1}$ cannot be rejected which means in this research, the model used is fixed effect.

\section{Hausman Test}

If the error valued of Hausman test is used to choose between fixed effect and random effect model. Hausman test is done by hypotheses as follow:

\section{$\mathrm{H}_{0}$ : Random effect model \\ $\mathrm{H}_{1}$ : fixed effect model}

If the failure probability valued less than $5 \%(0.05)$, then $\mathrm{H}_{0}$ can be rejected and $\mathrm{H}_{1}$ can ot be rejected which means that model used is fixed effect. In other hand, if the probability value is more than $5 \%$ then $\mathrm{H}_{0}$ is cannot be rejected and $\mathrm{H}_{1}$ can be rejected which means that the model used is common effect model. Based on the result Hausman test value of Cross -section random (0.0217) is less than 0.05 mean $\mathrm{H}_{0}$ can be rejected and $\mathrm{H}_{1}$ cannot be rejected which means in this research, the model used is fixed effect.

\section{Fixed Effect Regression Model}

Based on selection criteria above, the best model to use in this research is fixed effect model. Estimate model of panel data where characteristic and time in every country is different. So, this model have different intercept and constanta (Widarjono, 2009). Fixed effect model result to panel data in ten regions/ cities of Central Java, (Purbalingga, Boyolali, Klaten, Sukoharjo, Jepara, Demak, Semarang, Kendal, Surakarta, and Semarang). Economic growth as dependent variable and foreign investment, labor, and human capital investment as independent variable can be explained thwough output as follow:

Table 2. Regression Output of Data Panel Use Fixed Effect Model and Least Square Dummy Variable (LSDV)

\begin{tabular}{|c|c|c|c|c|}
\hline Variable & Coefficient & Std. Error & t-Statistic & Prob. \\
\hline $\bar{C}$ & -8.074591 & 1.734647 & -4.654890 & 0.0000 \\
\hline LNFDI? & 0.002026 & 0.031954 & 0.063409 & 0.9498 \\
\hline LNLABOR? & 0.552351 & 0.144952 & 3.810574 & 0.0005 \\
\hline $\mathrm{HCl}$ ? & 0.088033 & 0.015585 & 5.648752 & 0.0000 \\
\hline _PURBALINGGA--C & 0.044790 & & & 0.0874 \\
\hline _BOYOLALI-C* & 0.144007 & & & 0.0193 \\
\hline KLATEN-C & 0.046215 & & & 0.0809 \\
\hline SUKOHARJO-C & 0.054451 & & & 0.0703 \\
\hline JEPARA-C & -0.083750 & & & 0.3084 \\
\hline DEMAK-C & -0.290923 & & & 0.9379 \\
\hline SEMARANG $-C^{*}$ & 0.312411 & & & 0.0021 \\
\hline KENDAL-C* & 0.102761 & & & 0.0402 \\
\hline SSURAKARTACITY - C* & -0.276668 & & & 0.0039 \\
\hline SEMARANGCITY--C & -0.053293 & & & 0.2054 \\
\hline
\end{tabular}

Source: Output Eviews, 2017

Fixed Effect model regression equation

$$
E G=-8.074591+0.002026 \operatorname{lnFDI}+0.552351 \operatorname{lnL}+0.088033 \mathrm{HCI}
$$

District/cities which significant using LSDV can be explained as follow: 
(1) Boyolali has significant coefficient, and it means there is difference with the main coefficient $(-8.074591)+(0.144007)=-7.9306584$. if independent variable is assumed as zero, then Boyolali has economic growth about - 7.9306584 percent.

(2) Semarang has significant coefficient, and it means there is difference with the main coefficient $(-8.074591)+(0.312411)=-7.76218$. if independent variable is assumed as zero, then Semarang has economic growth about -7.76218 percent.

(3) Kendal has significant coefficient, and it means there is difference with the main coefficient ($8.074591)+(0.102761)=-7.97183$. if independent variable is assumed as zero, then Kendal has economic growth about -7.97183 percent.

(4) Surakarta as benchmark has significant coefficient, and it means there is difference with the main coefficient $(8.074591)+(-0.276668)=-8.351259$. if independent variable is assumed as zero, then Surakarta has economic growth about -8.351259 percent.

(5) Conclusion can be taken from the result of LSDV that regions/ cities with highest economic growth is Semarang because Semarang has the highest coefficient rather than another which have value -7.76278 percent.

(6) Economic growth analysis in ten regions/ cities of Central Java in 2011-2015.

From analysis used fixed effect model, intercept or constant from economic growth in ten regions/ cities of Central Java in 2011-2015 has negative value 8.938846. In other hand can be concluded that the independent variables (foreign investment, labor, and human capital investment) has constant value (zero) then the economic growth is -8.938846 . Negative constanta has no matter and can be avoid as long as the regression test is completed the assumption (classical and normality), as long as the slope value is not zero, the negative constanta will no matter because basically regression is used to predict the value of $Y$ based on $X$ change (Dougherty, 2002).

\section{$\mathbf{R}^{2}$ Coefficient Determination}

Coefficient determination $\left(R^{2}\right)$ is to measure how far the model explain the dependent variable. Coefficient determination value is zero and one. Small $R^{2}$ means that the ability of independent variables in explaining the dependent variable variation is very limited. Based on data processed, the value of coefficient determination of adjusted $R^{2}$ is 0.751506 . it shows that economic growth variable is able to be explained by independent variables which in this research is foreign investment, labor, and human capital investment 75.15 percent.

\section{Goodness of Fit Test (F Test)}

$\mathrm{F}$ test (simultan regression slope test) is used to measure whether all independent variables are significantly affected to dependent variables and to know that regression model can be used or in other hand is the independent variables can predict the dependent variable. $F$ test in this research is foreign investment, labor, and human capital investment influence simultanously to dependent variable which is economic growth of ten regions/ cities in Central Java in 2011-2015. The result of $F$ test shows as follow

Table 3. F Test Output

\begin{tabular}{ll}
\hline Value F Statistic & 13.34899 \\
Prob (F Statistic) & 0.000000 \\
Significantly & Significant \\
\hline
\end{tabular}

Source: Output Eviews, 2017

According to Table 3, probability of F statistic is 0.000000 and it values less than $(\alpha=0.05)$ which means that foreign investment, labor, and human capital investment are simultanously affected significantly to economic growth in ten regions/ cities of Central Java in 2011-2015. 


\section{Parametric Individual Test (t Test)}

$t$ test is used to know the partial effect of each independent variable to economic growth in 20112015. $t$ table calculation in this research use significant level $(\alpha=0.05)$. statistical test shows as follow:

Table 4. t Test Output

\begin{tabular}{lccc}
\hline Variable & Coefficient & t-Statistic & Sig. \\
\hline Constant & -8.074591 & -4.654890 & 0.0000 \\
Foreign Direct Investment $(\operatorname{InX} 1)$ & 0.002026 & 0.063409 & 0.9498 \\
Labor (InX2) & 0.552351 & 3.810574 & 0.0005 \\
Human Capital Invetment (X3) & 0.088033 & 5.648752 & 0.0000 \\
\hline
\end{tabular}

Source: Output Eviews, 2017

Based on the calculation, failure of probability result is less than 0.05 . Means that foreign investment is not significantly affected to economic growth in ten regions/ cities of Central Java in 2011-2015 but labor and human capital investment are significantly affected to economic growth in ten regions/ cities of Central Java in 2011-2015.

\section{DISCUSSION}

Effect of Foreign Investment to Economic growth in Ten Regions/Cities of Central Java in 2011-2015 Foreign investment which measured by realization in ten regions/ cities known that after regression, foreign investment has no significant effect to economic growth, so the result does not in accordance with hypothesis that formerly said there is positive effect between foreign investment and economic growth.

The result does not in accordance with Harrod-Domar theory and the research by Hikmatiyar and Hayati (2013) as well who stated that there is significant and positive effect between foreign investment and PDRB per capita in Central Java 1999-2009. In this research foreign investment is not significant, it is cause less condusive investment climate such as the complexity of investment licensing process and not optimally explored resources in ten regency/cities of central java province.

\section{Effect of labor to economic growth in ten regions/ cities of Central Java in 2011-2015}

Based on regression result, labor has positive and significant effect to economic growth in ten regions/ cities of Central Java in 2011-2015. Coefficient regression of labor is 0.552351 means that if labor is increasing at least one percent, the economic growth will increase 0.5 percent as well. Neoclassical theory strengthen the result that one of input or factors that influence the economic growth is labor so it can be concluded that in ten regions/ cities of Central Java in 2011-2015 still need labor as production factor of goods or services.

Research by Pambudi (2013), Barimbing, Karmini (2015), and Chong Hong, Wenqing (2012) who stated that labor influence the economic growth is comply with this research that shows the influence of labor in ten regions/ cities of Central Java in 2011-2015. As driving force, labor is an important input to encorging economic growth, as all business activities in economy definitely require labor. The large number of worker/labor should be support by job opportunities, therefor the economic structure of the region/cities in Central Java province is still supported by labor as the main input (Labor Intensif).

\section{Effect of Human Capital Investment to economic growth in ten regions/ cities of Central Java in 2011-2015}

Human capital investment which measure with Human Development Index (HDI) is considered human as a capital just like the other kind of capital such as machines, technologies, lands, money, and materials (Schults, 1961). Regresseion result shows that human capital investment is influence significant and positively ro economic growth in ten regions/ cities of Central Java in 2011-2015. The 
coefficient value of human capital investment is 0.088033 means that every one additional of human capital investment will increase the economic growth 0.08 percent.

Research by Nadmbiri, Ritho, Ng'ang'a, Kubown, Mairura, Nyangweso, Mairuru, and Cherotwo (2012). Chong, Hong, and Wenqing PAN (2012) is strengthen the resukt that there is positive and significant influence between labor and economic growth. Human capital investment variables proved to have positive and significant in boosting economic growth, this proves that three basic components: longevity and healthy living are measured by life expectancy, knowledge measured by literact rate and average lenghth of education and decent living standarts that measured by purchasing power parity, have been concern to the government. One of the forms of attention made by local and provincial government is the provision of educational assistance in the form of compulsory 12 years of studt and scholarship for students who come from central java province.

\section{CONCLUSION}

Based on the result of data panel regression estimation with fixed effect model explaining foreign investment variable, labor, and human capital investment that simultaneously have significant effect to economic growth in ten districts / cities in Central Java Province in 2011-2015 and ability of independent variables to describes the dependent variable is 81.23 percent.

Based on the result of panel data regression estimation with fixed effect model (FEM) with significance level 5 percent. Partially labor and human capital investment have a significant and positive effect, but foreign investment (PMA) has positive and insignificant effect on economic growth in ten regencies / cities in Central Java Province in 2011-2015.

\section{REFERENCES}

Bai, C. En., dan Pan, Wenqing., dan Ma, Hong. (2012). Spatial Spillover And Regional Economic Growth In China. http://www.ppge.ufrgs.br/sabino/ecod03/bibl/cer\%201.pdf. Diakses 16 september 2016.

Badan Pusat Statistik Provinsi Jawa Tengah. 2012-2016. Provinsi Jawa Tengah dalam Angka. Semarang.

Badan Pusat Statistik Indonesia. 2012-2016. Statistik keuangan Pemerintah Kabupaten/Kota. Jakarta.

Badan Pusat Statistik Indonesia. 2011-2015. Keadaan Angkatan Kerja Jawa Tengah. Jakarta.

Badan Pusat Statistik Provinsi Jawa Tengah. 2015. Profil Ketanagakerjaan Jawa Tengah. Semarang

Barimbing, Y Barimbing dan Karmini, N Luh. (2015). Pengaruh PAD, Tenaga Kerja, Dan Investasi Terhadap Pertumbuhan Ekonomi Di ProvinsiBali. http://ojs.unud.ac.id/ index.php/eep/article/viewFile/12125/9110, accessed on 20 September 2016.

Gunawan, D.S. (2015). Dimenspasi Spasial Pembangunan Ekonomi Indonesia 1994-2012. Disertasi. Doktor Ilmu Ekonomi Universitas Gadjah Mada. Yogyarta. (Tidak Dipublikasikan).

Gujarati, D \& Porter, D. (2009). Basic Econometrics. McGraw-Hill. New York.

Gujarati, Damodar N. (2012). Dasar-dasar Ekonometrika. Salemba empat. Jakarta.

Mankiew, N Gregory. (2006). Makroekonomi. Edisi Keenam.Penerbit Erlangga. Jakarta

Mudrajat. K. (2012). Masalah,Kebijakan, Dan Politik Ekonomi Pembangunan. Penerbit Erlangga. Jakarta.

Nachrowi, D Nachrowi dan Usman Djalal. (2002). Penggunaan Teknik Ekonometrika. Penerbit RajaGrafindo Persada. Jakarta.

Ndambiri, H.K et al. (2012). Determinants Of Economic Growth In Sub-Saharan Africa: A Panel Data Approach. http://www.omicsonline.com/open-access/determinants-of-economic-growth-insubsaharan-africa-a-panel-data-approach-2162-6359-2-121.pdf, diakses 15 September 2016. 
Pambudi, E Wicaksono. (2013). Analisis Pertumbuhan Ekonomi Dan Faktor-Faktor Yang Mempengaruhi (Kabupaten/Kota Di Provinsi JawaTengah). http://eprints.undip.ac.id/38749/1/ EKO.pdf, diakses 16 September 2016.

Putriana. (2016). Analisis Faktor-Faktor Yang Mempengaruhi Pertumbuhan Ekonomi di Provinsi Jawa Barat Periode 200-2014. Skripsi. Sarjana Universitas Jenderal Soedirman. Purwokerto. (Not Published).

Sunusi, D.K., Kumenaung, A., dan Rotinsulu, D. (2014). Analisis pengaruh Jumlah Tenaga Kerja, Tingkat Pendidikan, Pengeluaran Pemerintah Pada Pertumbuhan Ekonomi Dan Dampaknya Terhadap kemiskinan di Sulawesi Utara Tahun 2001-2010. file://C:/Users/Hanny/Downloads/4732-9107-1-SM.pdf, diakses 15 September 2016.

Widarjono, Agus. 2007. Ekonometrika: Teori dan Aplikasi untuk Ekonomi dan Bisnis. Edisi Kedua. Penerbit Ekonisia. Yogyakarta. 